\title{
VARIABEL LATEN SEBAGAI MODERATOR DAN MEDIATOR DALAM HUBUNGAN KAUSAL
}

\author{
I Komang Gede Antara ${ }^{1}$, I Putu Eka Nila Kencana ${ }^{2}$, \\ KETUT JAYANEGARA ${ }^{3}$ \\ 1,2,3 Jurusan Matematika FMIPA Universitas Udayana, Bukit Jimbaran-Bali \\ e-mail: ${ }^{1}$ tiangkembar@yahoo.co.id, ${ }^{2}$ I.Putu.ENK@gmail.com, ${ }^{3}$ ketut_jayanegara@yahoo.com
}

\begin{abstract}
Latent variables are variables that can not be measured directly. In analysis of causal relationship involving three latent variables, one latent variable can be a moderator or mediator variables. Goodness of Fit moderation and mediation model of latent variables is affected by the value of the canonical correlation between moderator/mediator latent variables with the independent latent variables and dependent latent variables. If the value of both canonical correlation is well, so the Goodness of Fit models of mediation is getting better, while the opposite Goodness of Fit models will be better moderation.
\end{abstract}

Keywords: Latent Variables, Moderator, Mediator, Canonical Correlation

\section{Pendahuluan}

Pada perkembangan analisis hubungan variabel, terutama analisis hubungan kausal, tidak hanya melibatkan dua variabel yaitu variabel bebas (independent variable) dan variabel terikat (dependent variable) akan tetapi juga melibatkan variabel ketiga yang bisa berupa variabel moderator (moderation variable) atau variabel mediator (mediation variable) [1]. Variabel moderator berfungsi untuk memperkuat atau melemahkan pengaruh variabel bebas, sedangkan variabel mediator berperan untuk menghantarkan pengaruh variabel bebas terhadap variabel terikat [7].

Lebih jauh mengenai perkembangan analisis hubungan variabel, saat ini juga berkembang analisis yang melibatkan suatu variabel yang tidak terukur atau dikenal dengan analisis variabel laten ${ }^{[4]}$, terutama analisis dalam dunia kesehatan, psikologi dan sosial. Pada analisis dengan meggunakan variabel laten dikenal dua analisis model yaitu model terukur (measurable model) dan model struktural (structural model)[8]. Model terukur merupakan model yang berkaitan dengan hubungan antara variabel laten dengan indikatornya, sedangkan model struktural merupakan model yang berkaitan dengan hubungan antara variabel laten dengan variabel laten yang lain [3].

\footnotetext{
${ }^{1}$ Mahasiswa Jurusan Matematika FMIPA Universitas Udayana

${ }^{2,3}$ Staf Pengajar Jurusan Matematika FMIPA Universitas Udayana
} 
Pada model struktural, apabila hubungan yang dibangun merupakan hubungan kausal maka satu variabel laten akan berperan sebagai variabel bebas (laten eksogen) dan variabel laten lainnya sebagai variabel terikat (laten endogen). Selanjutnya apabila hubungan kausal yang terjadi melibatkan tiga variabel laten maka variabel laten yang ketiga dapat berupa moderator atau mediator pada hubungan dua variabel laten yang lain.

Penentuan variabel laten sebagai moderator atau mediator menjadi sangat penting dalam suatu analisis sebab akan mempengaruhi Goodness of Fit model yang dihasilkan. Pada variabel terukur, signifikansi hubungan antara ketiga variabel yang membentuk model moderasi atau mediasi menjadi syarat terjadinya model moderasi ataupun mediasi ${ }^{[1]}$. Namun dalam model moderasi atau mediasi yang melibatkan variabel laten, Goodness of Fit model tidak dapat secara langsung ditentukan dari signifikansi korelasi antarvariabel, sebab variabel laten merupakan suatu gugus variabel yang terdiri dari indikator-indikator terukur. Hubungan antarvariabel laten ditentukan dari korelasi kanonik antarvariabel laten. Pada penelitian ini dianalisis pengaruh besar korelasi kanonik antarvariabel laten dengan Goodness of Fit model yang dihasilkan pada model moderasi dan mediasi variabel laten.

\section{Metode Penelitian}

Data yang digunakan pada penelitian ini adalah data sekunder yang diperoleh dari tulisan mengenai analisis derajat kesehatan masyarakat provinsi Bali [6]. Data yang diambil berupa tiga variabel laten, yaitu pertama variabel laten ekonomi dengan indikator penyusunnya adalah jumlah penduduk sebagai petani, jumlah penduduk produktif, dan jumlah anggota Koperasi Unit Desa (KUD). Variabel laten yang kedua adalah variabel laten derajat kesehatan dengan indikator penyusunnya adalah angka kematian ibu, angka kematian bayi, status gizi balita, dan jumlah kasus TB paru. Variabel laten terakhir adalah variabel laten lingkungan dengan indikator penyusunnya adalah persentase rumah sehat, persentase keluarga memiliki sumber air terlindung dan persentase keluarga yang memiliki jamban.

Sebagai batasan masalah dalam penelitian ini adalah hubungan masingmasing indikator bersifat reflektif. Selain itu pembahasan hasil hubungan indikator terhadap variabel laten yang dibentuknya tidak diinterprestasikan, sebab yang menjadi fokus penelitian adalah besar pengaruh antara variabel laten dengan varaibel laten yang lain dalam peranannya pada model moderasi dan model mediasi.

Adapun teknik analisis data pada penelitian ini dilakukan dengan langkahlangkah berikut ini :

i. Menghitung matrik korelasi kanonik dari tiga variabel laten yang digunakan. Korelasi yang terjadi antarvariabel laten yang tersusun dari sejumlah 
indikator dihitung dengan menggunakan korelasi kanonik. Variabel laten yang berkorelasi merupakan suatu gugus variabel dengan indikator-indikator terukur penyusunnya sebagai gugus variabel, sehingga korelasi kanonik tepat digunakan karena mampu melihat korelasi antargugus variabel [5]. Besar korelasi kanonik ditentukan dari beberapa fungsi kanonik yang dihasilkan. Pemilihan banyak fungsi kanonik yang digunakan untuk menjelaskan korelasi kanonik antargugus variabel dapat dilakukan dengan melihat besar kontribusi keragaman kumulatif yang dijelaskan oleh setiap fungsi kanonik tersebut [5].

ii. Mengestimasi parameter Structural Equation Modeling (SEM) dari variabel laten dalam peranannya sebagai moderator atau mediator. Estimasi parameter dari variabel laten dilakukan dengan pendekatan Partial Least Square (PLS) yakni dengan metode kuadrat terkecil, seperti pada regresi linier [3]. Besar pengaruh indikator terhadap variabel laten yang disusunnya dapat dilihat pada Outer Loadings (indikator bersifat replektif) dan Outer Weights (indikator bersifat formatif). Besar pengaruh antarvariabel laten dapat dilihat pada besar Path Coefficients.

iii. Mengidentifikasi model terbaik. Goodness of Fit model diukur dengan menggunakan $R^{2}$ dari variabel laten yang berperan sebagai variabel terikat dalam model kemudian dicari nilai $Q^{2}$ yang merupakan predictive relevance untuk model tersebut. $Q^{2}$ dicari dengan persamaan

$$
Q^{2}=1-\left(1-R_{1}{ }^{2}\right)\left(1-R_{2}{ }^{2}\right) \ldots\left(1-R_{p}{ }^{2}\right)
$$

dengan $R_{1}{ }^{2}, R_{2}{ }^{2} \ldots R_{p}{ }^{2}$ merupakan $R^{2}$ dari variabel laten terikat dalam model. Nilai $Q^{2}$ berada pada rentang 0 sampai 1 , semakin mendekati 1 maka model yang dibentuk semakin baik [3].

iv. Menduga keterkaitan antara nilai koefisien korelasi kanonik dengan peranan variabel laten sebagai moderator atau mediator. Besar korelasi kanonik antarvariabel laten diduga memberikan pengaruh pada terjadinya model moderasi atau mediasi dari variabel laten, seperti halnya pengaruh korelasi pada variabel terukur merupakan suatu asumsi yang harus terpenuhi terhadap terjadinya model mediasi ataupun moderasi pada variabel terukur [1]. Sebagai contoh korelasi variabel independen dan variabel mediator harus signifikan begitu juga korelasi dari variabel mediator juga harus signifikan terhadap variabel dependen sebagai asumsi yang harus dipenuhi dalam model mediasi.

\section{Hasil dan Pembahasan}

Sebagai tahap awal analisis dilakukan dengan menentukan besar korelasi kanonik antarvariabel laten, yaitu variabel ekonomi, variabel lingkungan dan variabel derajat kesehatan. Besar korelasi kanonik antarvariabel laten ditunjukkan pada Gambar 1. Pada Gambar 1 terlihat korelasi kanonik yang tidak terlalu kuat terjadi antara variabel laten ekonomi dengan variabel laten lingkungan dan variabel laten lingkungan dengan variabel laten derajat kesehatan sebab besar 
korelasi kanonik yang dihasilkan di bawah 0,5.

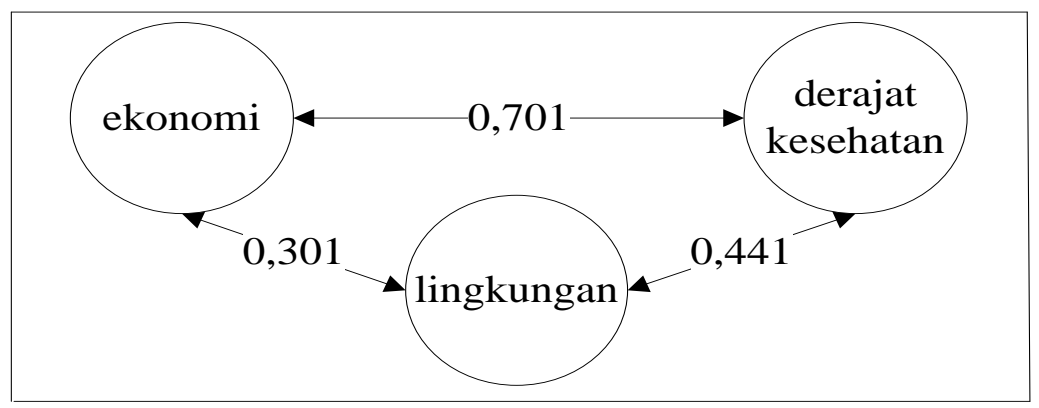

Sumber : Data diolah 2013

Gambar 1. Korelasi kanonik ketiga variabel laten

Tahap berikutnya adalah menentukan Goodness of Fit model mediasi dan model moderasi dari variabel laten. Model mediasi dibentuk ketika variabel lingkungan sebagai variabel mediator terletak di tengah pengaruh langsung variabel ekonomi terhadap variabel derajat kesehatan (Gambar 3). Model moderasi dibentuk ketika variabel lingkungan sebagai variabel moderator, selanjutnya melakukan interaksi dengan variabel ekonomi sebagai variabel prediktor dengan membentuk variabel baru yaitu variabel ekonomi*lingkungan yang juga memberikan pengaruh langsung terhadap variabel derajat kesehatan (Gambar 4). Besar pengaruh mediasi dan moderasi ditentukan dari besar perubahan pengaruh langsung variabel ekonomi terhadap variabel derajat kesehatan sebelum dan sesudah dibentuk model moderasi dan mediasi [2].

Pengaruh langsung variabel ekonomi terhadap variabel derajat kesehatan sebelum adanya variabel lingkungan baik sebagai moderator maupun sebagai mediator dalam model adalah sebesar -0,560 (Gambar 2). Besaran -0,560 dapat menginterprestasikan peningkatan indikator pada varaibel laten ekonomi mengakibatkan penurunan sebesar 0,560 terhadap indikator pada variabel laten derajat kesehatan. Setelah variabel lingkungan berperan sebagai mediator (Gambar 3) pengaruh langsung variabel ekonomi terhadap variabel derajat kesehatan menjadi $-0,513$ sehingga besar pengaruh mediasi variabel lingkungan adalah sebesar 0,047 .

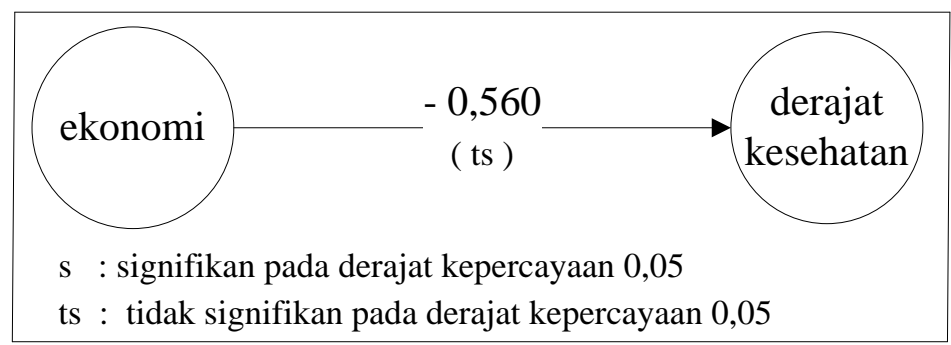

Sumber : Data diolah 2013

Gambar 2. Output hubungan langsung ekonomi dengan derajat kesehatan 


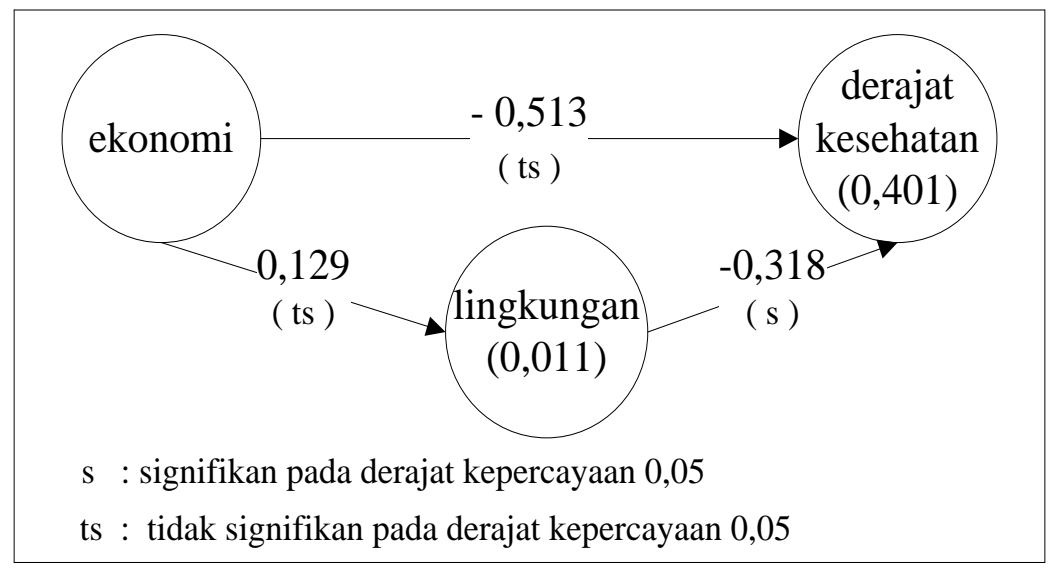

Sumber : Data diolah (2013)

Gambar 3 Output mediasi ekonomi dan derajat kesehatan oleh lingkungan

Penurunan pengaruh langsung variabel ekonomi terhadap variabel derajat kesehatan diakibatkan oleh pengaruh perantara atau pengaruh mediasi dari variabel lingkungan yaitu sebesar $0,129 *(-0,318)=-0,0410$ (Gambar 3)[3]. Pengaruh moderasi terjadi ketika variabel baru yang merupakan interaksi antara variabel ekonomi dengan variabel lingkungan (ekonomi*lingkungan) memberikan pengaruh langsung terhadap variabel derajat kesehatan (Gambar 4), sehingga mempengaruhi perubahan pengaruh langsung variabel ekonomi terhadap variabel derajat kesehatan menjadi -0,246 (Gambar 4), sehingga besar pengaruh moderasi adalah 0,314 .

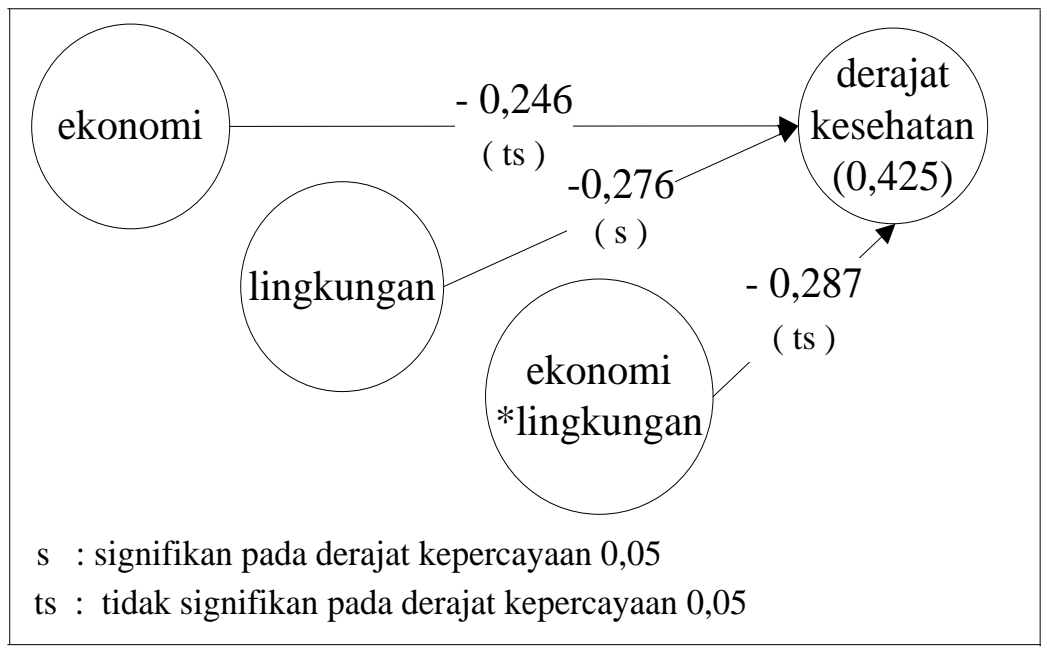

Sumber : Data diolah (2013)

Gambar 4 Output moderasi ekonomi dan derajat kesehatan oleh lingkungan

Memerhatikan besar pengaruh moderasi dan mediasi dari variabel lingkungan, maka variabel lingkungan lebih efektif sebagai moderator dari hubungan langsung variabel ekonomi dengan variabel derajat kesehatan. Hasil Goodness of Fit model moderasi maupun mediasi menunjukkan model moderasi 
lebih baik dari pada model mediasi. Goodness of Fit model ditentukan dari besar $Q^{2}$ yang dihasilkan model, nilai $Q^{2}$ mendekati 1 maka Goodness of Fit model semakin baik.

Besar $R^{2}$ untuk variabel laten yang berperan sebagai variabel terikat dalam model mediasi yaitu variabel lingkungan dan variabel derajat kesehatan berturutturut 0,011 dan 0,401 (Gambar 3) sehingga besar $Q^{2}$ model mediasi adalah :

$$
Q^{2}=1-(1-0,011)(1-0,401)=0,407
$$

Besar $Q^{2}$ model moderasi diperoleh sebesar 0,425 dengan $R^{2}$ untuk variabel laten yang berperan sebagai variabel terikat yaitu variabel derajat kesehatan adalah 0,425 (Gambar 4)

$$
Q^{2}=1-(1-0,425)=0,425
$$

Hasil analisis menunjukkan besar korelasi kanonik antara variabel laten lingkungan sebagai moderator/mediator dengan variabel laten ekonomi sebagai variabel bebas dan variabel laten derajat kesehatan sebagai variabel terikat yaitu berturut-turut sebesar 0,301 dan 0,441 memengaruhi Goodness of Fit model moderasi yang lebih baik dari model mediasi. Goodness of Fit model moderasi yaitu sebesar 0,425 sedangkan Goodness of Fit model mediasi sebesar 0,407.

\section{Kesimpulan}

Berdasarkan hasil yang telah diperoleh besar korelasi kanonik variabel laten yang berperan sebagai moderator atau mediator yaitu variabel lingkungan dengan variabel ekonomi dan variabel derajat kesehatan memengaruhi Goodness of Fit model mediasi dan model moderasi. Besar korelasi kanonik variabel laten moderator atau mediator dengan variabel laten bebas dan variabel laten terikat di bawah 0,5 menyebabkan Goodness of Fit model moderasi lebih baik dibandingkan dengan model mediasi. Sebaliknya dengan korelasi kanonik variabel laten moderator atau mediator dengan variabel laten bebas dan variabel laten terikat di atas 0,5 maka diduga menyebabkan model mediasi lebih baik dari model moderasi, tetapi belum dapat ditentukan besaran korelasi kanonik yang tepat sehingga model mediasi lebih baik dari model moderasi.

\section{Daftar Pustaka}

[1] Baron, R.M. and D.A. Kenny. 1986. "The Moderator-Mediator Variable Distinction in Social Psychological Research : Conceptual, Strategic, and Statistical Consideration". Journal of Personality and Social Psychology 1986, vol.51. No.6. 1173-1182.

[2] Edelman, L.F., C.G. Brush., and T. Manolova. 2002. "The Mediating Role of Strategy on Small Firm Performance". Journal of Business venturing. 
[3] Jaya, I.G.N.M. dan I. M. Sumertajaya. 2008. "Pemodelan Persamaan Struktural dengan Partial Least Square". Semnas Matematika dan Pendidikan Matematika 2008.

[4] Loehlin, J.C. 2004. Latent Variable Models An Introduction to Factor, Path and Structural Equation Analysis Fourth Edition. London: Lawrence Erlbaum Associates, Inc.

[5] Mattjik, A.A., dan I.M. Sumertajaya. Sidik Peubah Ganda. Bogor: Institut Pertanian Bogor Press.

[6] Ningsih, P.N.P., 2013. Analisis Derajat Kesehatan Masyarakat Provinsi Bali Dengan Metode Generalized Structured Component Analysis (Gsca). Skripsi. Jurusan Matemtika, Fakultas Matematika dan Ilmu Pengetahuan Alam, Universitas Udayana. Jimbaran

[7] Preacher, K.J., D.D. Rucker., and A.F. Hayes. 2007. "Addressing Moderated Mediation Hypothesis: Theory, Methods, and Prescriptions". Multivariate Behavioral Research.42(1).185-227.

[8] Skrondal, A. and S. Rabe-Hesketh. 2005. "Structural Equation Modeling: Categorical Variable". Entry for the Encyclopedia of Statistic in Behavioral Science. 